\title{
THE
}

\section{Equity in Community Forests in Bhutan}

\author{
Bill Buffum \\ University of Rhode Island, bill_buffum@uri.edu
}
A. Lawrence
K. J. Temphel

Follow this and additional works at: https://digitalcommons.uri.edu/nrs_facpubs

Terms of Use

All rights reserved under copyright.

\section{Citation/Publisher Attribution}

Buffum, B., Lawrence, A., \& Temphel, K. J. (2010). Equity in Community Forest in Bhutan. International Forestry Review, 12(3), 187-199. https://doi.org/10.1505/ifor.12.3.187

Available at: https://doi.org/10.1505/ifor.12.3.187

This Article is brought to you for free and open access by the Natural Resources Science at DigitalCommons@URI. It has been accepted for inclusion in Natural Resources Science Faculty Publications by an authorized administrator of DigitalCommons@URI. For more information, please contact digitalcommons-group@uri.edu. 


\section{BioOne COMPLETE}

\section{Equity in Community Forests in Bhutan}

Authors: Buffum, B., Lawrence, A., and Temphel, K. J.

Source: International Forestry Review, 12(3) : 187-199

Published By: Commonwealth Forestry Association

URL: https://doi.org/10.1505/ifor.12.3.187

BioOne Complete (complete.BioOne.org) is a full-text database of 200 subscribed and open-access titles in the biological, ecological, and environmental sciences published by nonprofit societies, associations, museums, institutions, and presses.

Your use of this PDF, the BioOne Complete website, and all posted and associated content indicates your acceptance of BioOne's Terms of Use, available at www.bioone.org/terms-of-use.

Usage of BioOne Complete content is strictly limited to personal, educational, and non - commercial use. Commercial inquiries or rights and permissions requests should be directed to the individual publisher as copyright holder.

BioOne sees sustainable scholarly publishing as an inherently collaborative enterprise connecting authors, nonprofit publishers, academic institutions, research libraries, and research funders in the common goal of maximizing access to critical research. 


\title{
Equity in Community Forests in Bhutan
}

\author{
B. BUFFUM ${ }^{1}$, A. LAWRENCE ${ }^{2}$ and K. J. TEMPHEL ${ }^{3}$ \\ 1 University of Rhode Island, Dept. of Natural Resources Science, 1 Greenhouse Road, Kingston, RI 02881, USA \\ ${ }^{2}$ Forest Research (The Forestry Commission), Alice Holt Lodge, Farnham, Surrey GU10 4LH, UK \\ ${ }^{3}$ Department of Forests, Ministry of Agriculture, Thimphu, Bhutan
}

Email: buffum@uri.edu, anna.lawrence@forestry.gsi.gov.uk, kj_temphel@yahoo.co.uk

\begin{abstract}
SUMMARY
The equity of Bhutan's new community forestry program was assessed after three years of experience with timber harvesting. Despite the impressive achievements of community forestry programs elsewhere in South Asia, there is increasing evidence that poor and disadvantaged members of community forestry management groups benefit less than other members. We compared this with the situation in Bhutan. All households in three villages were ranked by socio-economic status before analyzing the distribution of community forest (CF) products. A household survey and focus group interviews provided more detailed information on how the socio-economic groups participated in the CFs. Economic equity (distribution of benefits) and political equity (participation in decision making) were found to be higher than reports from neighbouring countries. We discuss the cultural context and hypothesise that these unexpected findings can be attributed to four factors: ethnic homogeneity, active participation of women, supportive government policy and intensive extension support. Further study with additional CFs over a longer time period is needed to test this hypothesis and assess the relative importance of these four factors.
\end{abstract}

Keywords: equity, Community Forestry, Bhutan, Himalayas

\section{Equité dans les forêts communautaires du Bhutan}

\section{B. BUFFUM, A. LAWRENCE et K. J. TEMPHEL}

L'équité du nouveau programme de foresterie communautaire au Bhutan a été évalué après trois ans d'expérience de récolte du bois. Malgré les succès impressionnants des programmes de foresterie communautaires dans d'autres parties de l'Asie du Sud, les preuves sont croissantes que les membres pauvres et défavorisés des groupes de gestion de la foresterie communautaire profitent moins de la situation que les autres membres. Nous avons comparé cela à la situation au Bhutan. Tous les foyers de trois villages étaient classés par status socio-économique avant l'analyse de la distribution des produits de la forêt communautaire ( CF). Une étude des foyers et des interviews de groupes focus fournit une information plus détaillée sur la manière dont les groupes socio-économiques participent dans les CF. L'équité économique ( la distribution des bénéfices) et l'équité politique ( la participation dans les prises de décision) s' avérèrent être plus hautes que celles des pays avoisinants. Nous étudions le contexte culturel et lançons l'hypothèse que ces résultats inattendus peuvent être attribué à quatre facteurs : l'homogénéité ethnique, la participation active des femmes, une politique gouvernementale d'encouragement et un soutien d'extension intensif. Une étude plus poussée dans d'autres CFs , pendant une période plus étendue est nécessaire pour tester cette hypothèse et évaluer l'importance relative de ces quatre facteurs.

\section{La equidad en los bosques comunitarios de Bután}

\section{B. BUFFUM, A. LAWRENCE y K. J. TEMPHEL}

Se ha llevado a cabo una evaluación de la equidad del nuevo programa de gestión forestal comunitaria de Bután después de tres años de experiencia de la cosecha maderera. A pesar de los logros impresionantes de programas de gestión forestal comunitaria en otras partes de Asia meridional, parece haber cada vez más pruebas de que los miembros pobres y desventajados de los grupos de gestión forestal comunitaria se benefician menos que los demás miembros. Esta realidad fue comparada con la situación en Bután. Todas las casas de tres aldeas fueron clasificadas por estatus socioeconómico antes de llevar a cabo un análisis de la distribución de productos procedentes de bosques comunitarios. Una encuesta sobre las casas y entrevistas con grupos de sondeo proporcionaron información más detallada sobre la participación en los bosques comunitarios de los diferentes grupos socioeconómicos. Se descubrió que la equidad económica (distribución de beneficios) y la equidad política (participación en la toma de decisiones) era mayor que lo sugerido por los informes procedentes de países vecinos. En el estudio se examina el contexto cultural, formando una hipótesis de que estas conclusiones inesperadas pueden ser atribuidas a cuatro factores: la homogeneidad étnica, la participación activa de las mujeres, una política gubernamental favorable y un apoyo de extensión intensivo. Para poner a prueba esta hipótesis y evaluar la importancia relativa de estos cuatro factores, hace falta realizar estudios adicionales en otros bosques comunitarios y con períodos de tiempo más largos. 


\section{INTRODUCTION}

Community forestry is widely recognized as having a positive impact on forest cover (Gautam and Watanabe 2004, Sakurai et al. 2004, Yadav et al. 2003) and providing a range of economic and social benefits (Carter 2005, Lawrence 2007, White and Martin 2002), but there is increasing evidence that community forestry programs do not provide benefits equally to all social groups (Hobley 2005, Schreckenberg et al 2006). The emerging equity issues are an important aspect of what the donor and practitioner literature has called the 'second generation' issues of community forestry (Lawrence 2007).

A large proportion of equity studies in community forestry are specific to India and Nepal (Lawrence 2007), countries characterized by stratified caste-based societies. The experience of both countries has influenced the development of community forestry in Bhutan, a neighbouring but culturally distinct country whose community forestry experience has not yet been analyzed in the academic literature. Compared with its neighbours, Bhutan has a much smaller population and more forest cover (WRI 2007). Most of the population is Buddhist and does not observe the caste system. Women participate actively in decision making about natural resources management (Duba et al 1998, UNESCO 2008). Several authors have claimed that Bhutanese culture has a positive influence on natural resources management (Penjore and Rapten 2004, TFDP 2000). However, there is concern that the equity problems in community forestry in neighbouring countries will also emerge in Bhutan. An analysis of equity issues in the context of Bhutan can contribute to a widening of the global discussion about causes and consequences of equity problems in community forestry.

Our study focused on political and economic equity within $\mathrm{CFs}$, and was part of broader research that also addressed the sustainability of forest management approaches in the CFs (Buffum et al. 2008, 2009). Equity issues examined in the study included differential access to products and decision making by wealthier and more influential users, discrimination against female members, and differential access to products by committee members. Two main research questions were addressed:

- Does the initial experience with community forestry in Bhutan indicate emerging problems with political and economic equity as documented in neighbouring countries?

- How do Bhutan's cultural, political and geographic conditions affect the equity of its community forestry program?

\section{Equity in Community Forestry}

Equity is a concept that is open to variations in meaning. Equity should not be confused with equality, and refers to 'whether something is fair, just, or impartial' (Poteete 2004: 3). Several authors have noted that equity is a culturally constructed concept that must be defined by the actors in a given context (Lawrence 2007, McKean 2000, Poteete 2004).
Consequently, the members of a CFMG may have a different concept of 'fairness' from that of outsiders, especially concerning the participation of women and marginal groups (Agarwal 2001, Nurse et al. 2004).

The equity of community forestry can be assessed in terms of the external or internal relationships of a CFMG. An important external relationship is with the government, as government policies may limit the handover of community forests $(\mathrm{CF})$ in regions containing valuable timber resources (Bhattarai 2006), impose restrictions on the use of CFs near national parks and protected areas (Cronkleton et al. 2008), or limit participation in CFMGs to communities that live adjacent to national forests (Bacalla 2006). A different type of external relationship is with future generations: Anand and Sen (1996) discuss the concept of intergenerational equity to ensure that future generations can attain a standard of living that is at least comparable to that of the present generation.

However, most studies of equity have looked at internal relationships, such as those between different socioeconomic groups, male and female members, or committee members and regular members. For the purposes of analysis it is helpful to separate the power and resource dimensions of the equity of these relationships. Mahanty et al. (2006), for example, distinguish between economic equity, which involves the distribution of benefits, and political equity, which involves participation in decision making and the ability of stakeholders to express their ideas and concerns. Agrawal and Gupta (2005) have argued that political equity in user groups is a prerequisite for economic equity.

Many recent studies in South Asia have documented a lack of economic equity in community forestry. Community forestry often does not provide direct benefits to disadvantaged households even while generating positive change at the community level (McDermott and Schreckenberg 2009). Studies in Nepal and India have documented cases in which management committees practiced favouritism in distributing products (Springate-Baginski et al. 2003, Varalakshmi 2002); rules were biased towards meeting the needs of wealthier households (Schreckenberg and Luttrell 2009, Adhikari 2005); influential members were allowed to graze their animals in CFs even when bylaws prohibited forest grazing (Pandit and Thapa 2004); the poorest members and Dalits (untouchables) had less access to CF products than the wealthier and higher castes (Adhikari 2005, Chhetry et al. 2005) and benefited less from loans from CFMG funds (Pokharel and Nurse 2004); and female-headed households benefited less from $\mathrm{CFs}$ than male-headed households (Adhikari 2005).

Many studies also document weak political equity in South Asian community forestry: in Nepal, studies found that management committees were dominated by men and high caste groups (Kellert et al. 2000), and many members did not understand the management planning process which exacerbated conflicts during the distribution of products (Maharjan 2001). Cultural norms discouraged women from participating in $\mathrm{CF}$ meetings in several countries (Springate-Baginski et al. 2003), and women were excluded 
from decision making in India and Nepal, even in so-called participatory CFMGs (Agarwal 2001).

\section{Community forestry in Bhutan}

Bhutan is a land-locked Himalayan country bordering with China (Tibet) and India, with an area of 40,006 square kilometers and an estimated population of 672,425 (RGOB 2005). Elevation ranges from $100 \mathrm{~m}$ near the Indian border to 7,554 $\mathrm{m}$ on the northern border with Tibet, which results in a diverse range of forest types. Bhutan has a rich biodiversity and is part of one of the ten global biodiversity 'hotspots' (MYERS et al. 2000).

Bhutan initiated a community forestry program in the early 1990s to increase community participation in the management of national forests. The community forestry legislation enables the traditional users of a national forest to apply for legal rights to manage a block of national forest. The process starts with the formation of a community forestry management group $(\mathrm{CFMG})^{1}$, which includes one member from each household that has traditionally used the forest. The member can be either male or female, and is generally, but not always, the head of the household. The CFMG then elects a management committee, whose first task is to coordinate the preparation of a CF management plan with technical assistance from the Department of Forests (DOF). The management plan specifies how the management committee will manage the forest, patrol the $\mathrm{CF}$, collect fees for forest products, and impose penalties for improper use ${ }^{2}$. The area of the CF should not be greater than 2.5 ha per participating household, but the forest is managed communally rather than allocating specific portions to individual members. Annual limits for timber harvesting must be based on a detailed forest resources assessment.

After the management plan is endorsed by the district administration and approved by the DOF, the management committee assumes responsibility for implementing and monitoring forest management activities. CFMG members can request permits to harvest trees, but must pay user fees to the CFMG fund and contribute several days of voluntary labour each year for activities such as tree planting and maintenance of firebreaks. The first CF in Bhutan was approved in 1997. Twenty four CFs had been approved in 2005 at the time of our study, and the number had surpassed 100 by 2009. Two evaluations of the community forestry program noted shortcomings in record keeping and CF administration, but concluded that the CFMGs were managing their CFs in accordance with their management plans (Oberholzer et al. 2003, Temphel et al. 2005).

\section{Description of research area}

The study area included the three first three CFs in Bhutan to start timber harvesting operations, and the only CFs in Bhutan which had completed at least one year of timber harvesting at the time of the study (table 1). The villages were typical of Bhutanese villages where agriculture is the major occupation and Buddhism has an important influence on society (Pommaret 1991). The study did not include any CFs in the southern part of the country where most residents are of Nepali origin, as the CFs in that region were just initiating harvesting operations and did not yet have experience with distribution of CF products. The studied CFs were located in Bumthang and Mongar Districts of Bhutan (figure 1). The

FIGURE 1 Map of Bhutan and Studied Community Forests

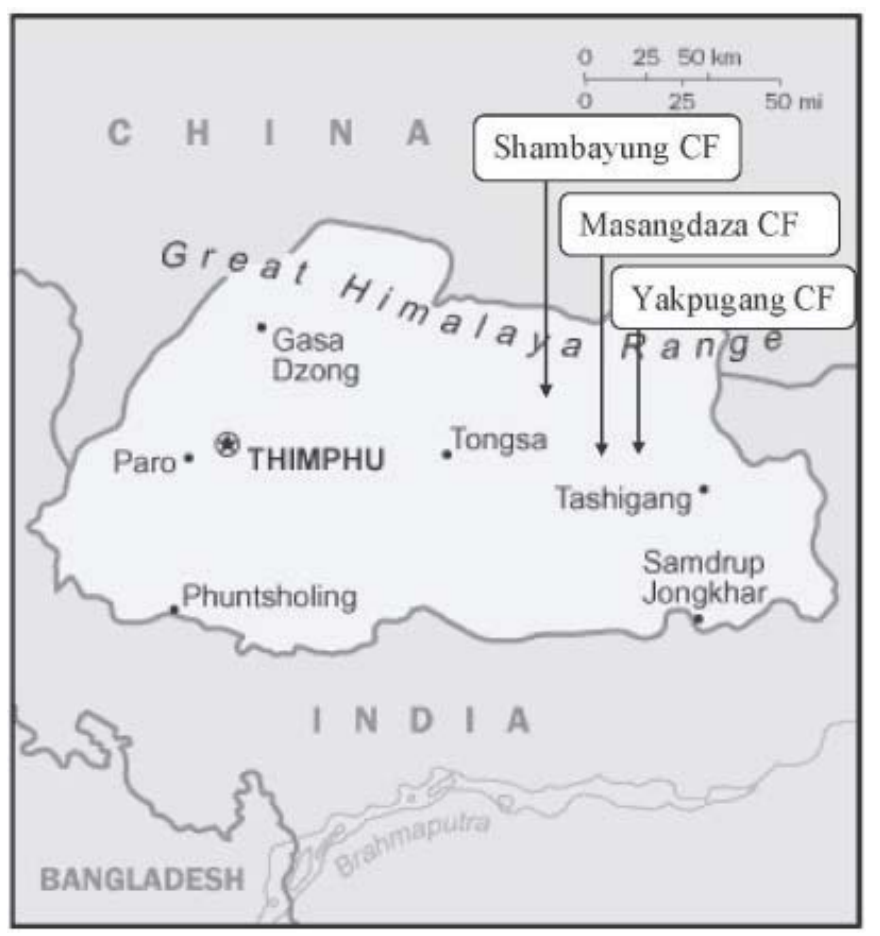

TABLE 1 Information on the Studied CFs

\begin{tabular}{|c|c|c|c|c|}
\hline & Yakpugang CF & Masangdaza CF & Shambayung CF & Average of all $24 \mathrm{CFs}$ \\
\hline Location & $\begin{array}{c}\text { Mongar District } \\
\text { Eastern Bhutan } \\
\left(7^{\circ} 15^{\prime} \mathrm{N} / 91^{\circ} 16^{\prime} \mathrm{E}\right)\end{array}$ & $\begin{array}{l}\text { Mongar District, } \\
\text { Eastern Bhutan } \\
\left(7^{\circ} 15^{\prime} \mathrm{N} / 91^{\circ} 10^{\prime} \mathrm{E}\right)\end{array}$ & $\begin{array}{l}\text { Bumthang District } \\
\text { Central Bhutan } \\
\left.27^{\circ} 36^{\prime} \mathrm{N} / 90^{\circ} 53^{\prime} \mathrm{E}\right)\end{array}$ & \\
\hline Elevation $(\mathrm{m})$ & 1,800 to 3,200 & 690 to 980 & 3,000 & \\
\hline Area (ha) & 260 & 87 & 46.5 & 90 \\
\hline Number households & 113 & 37 & 23 & 50 \\
\hline Date of handover & 2001 & 2002 & 2003 & \\
\hline Predominant religion & Buddhism & Buddhism & Buddhism & \\
\hline Local language & Sharchopa & Sharchopa & Bumthangkha & \\
\hline
\end{tabular}


major agricultural crops varied with elevation, including maize, rice, potatoes and buckwheat. Almost all households raised cattle, with a few households also owning yaks. During the dry season, many residents worked as labourers for road construction or other infrastructure development projects to supplement their farm income. All residents owned their own houses and at least some agricultural land, however some residents had much larger homes and land holdings than others, as will be discussed in the methodology section. All three villages had road access, but only a few residents owned motorcycles and none owned cars. School attendance in recent years had increased, but most adults never attended school, and the adult literacy rate was close to the national average of $47 \%$ (UNDP 2006).

All households in the three villages participated in the CFMGs except in Yakpugang CF, where residents of two adjacent villages were also given the option to join. The decision to join by the residents of adjacent villages depended largely on proximity to the $\mathrm{CF}$ and willingness to contribute labour for $\mathrm{CF}$ activities. Most members considered timber to be the most important CF product. The members had to obtain permits from the CFMG to harvest live trees for timber or firewood. The CFs were also used by most members for forest grazing and collection of dry firewood and non-wood products (NWFPs), activities which did not require permits. In all three CFs women collected most of the dry firewood and NWFPs, men harvested most of the timber and live firewood, and men and women participated equally in tending livestock in the CFs.

The boundaries of the CFs generally followed the traditional forest boundaries of the village, with some reductions to meet the $2.5 \mathrm{ha}$ /household limit for CFs set by the government. Many villages in Bhutan still observe traditional forest boundaries despite the nationalization of forests in 1969 which eliminated the legal basis for village forests (Wangchuk 2000).

\section{METHODOLOGY}

The study was based on a combination of methods and data sources, and used qualitative and quantitative approaches in complementary ways to define wealth and equity indicators, test the relationship between them and draw on local explanations for results.

\section{Equity indicators}

An important aspect of the methodology was establishing indicators of economic and political equity. Indicators of economic equity were based on the utilization of $\mathrm{CF}$ products, as in other studies (Adhikari 2005, Malla et al 2003). To ensure these indicators were relevant to the Bhutanese context, focus group sessions of CFMG members and government staff were conducted to prioritize the most important CF products/services (timber, firewood, forest grazing and non-wood forest products (NWFPs) and establish indicators related to their utilization. The management plans of all three CFs specified that all users should contribute equally to the $\mathrm{CF}$ and be entitled to an equal share of the benefits, regardless of their family size or need for CF products. The "fairness" of this system from the perspective of CFMG members was assessed through the household survey and informal discussions with community members.

Indicators of political equity were based on representation in the management committees and awareness of CF administration, following the approach of Malla et al. (2003), and included the representation in the $\mathrm{CF}$ management committees of women and poorer members, attendance at CF meetings, and knowledge about the $\mathrm{CF}$ fund. These indicators were discussed and endorsed during the focus group sessions, and the "fairness "of CF management was assessed through the household survey and direct observation of CF meetings.

\section{Data sources and collection methods}

A household survey was administered in March 2005 in three CFs to identify statistically significant trends in the management and utilization of the CFs and adjacent national forests. Including more than just three CFs in the study would have been preferable, but the sample included all of the experienced CFs at the time of the study. In 2005, the studied CFs were in their third or fourth year of timber harvesting operations, whereas no other CF in Bhutan had yet completed a year of harvesting. Otherwise the three studied CFs were generally representative of the 24 approved CFs at the time - two of the studied CFs were smaller than average in terms of the number of participating households and total area, whereas Yakpugang CF had the largest membership and area of all CFs at the time (table 1).

Before selecting the respondents for the household survey, all CFMG households in the three CFMGs were categorized into four socio-economic groups through a wealth ranking exercise carried out by a team of five or more persons at each site, including the responsible extension agent and three or more community leaders. The objective of the wealth ranking exercise was to identify locally important criteria for distinguishing households according to wealth and status, and to stratify the respondents of the household survey by socio-economic status in order to assess differences in the utilization of $\mathrm{CF}$ products and participation in the management of the $\mathrm{CF}$.

The criteria for the four socio-economic groups were established in consultation with community leaders during the wealth ranking exercises and were based on the primary source of income, land and livestock holdings, size/quality of house, and ownership of vehicles and mechanized equipment:

- Labourer: Earned most income from daily wage labour; had limited land holdings (usually just a kitchen garden) and livestock; owned a smaller than average house.

- Small Farmer: Produced most of his/her food; supplemented income with seasonal daily wage 
labour; had average holdings agriculture land and livestock; sold a small amount of agricultural production, owned an average size house.

- Large Farmer: Sold lots of surplus agriculture production; had very good agricultural land and/ or livestock; owned a power tiller, motorcycle or chainsaw; owned a larger than average house.

- Salary Earner: Owned a private business (such as contractor) or worked for the government; owned a vehicle, power tiller, motorcycle or chainsaw; owned a larger than average house.

Other options for wealth ranking were considered but found to be less appropriate for Bhutanese conditions. For example, Malla et al. (2003) categorized CFMG members in Nepal into four groups based largely on the number of months that they were self-sufficient for food production. Since each of the three CFs in Bhutan was ethnically homogenous and did not observe the caste system, it was not necessary to follow the common practice of stratifying the households by ethnic group or caste.

The three CFMGs contained roughly equal mixes of the four socio-economic groups (table 2). The labourers were consistently described by other villagers as being the "poorest" group in the village, and expressed the same view about themselves, while the salary earners were consistently described as being the "richest". In this paper, the terms "rich" and "poor" are used in relation to these four socioeconomic categories.

A random sample of households stratified by $\mathrm{CF}$ and socio-economic group included $29 \%(\mathrm{~N}=50)$ of the total 173 households of the three CFs. All of the interviews were conducted by one or more of the authors with the assistance of an interpreter. The official members of the CFMGs were interviewed unless unavailable, in which case another family member was interviewed.

The gender of the membership varied considerably in the CFs, being largely female in Shambayung, largely male in Masangdaza, and balanced in Yakpugang (table 2). The high membership of women can be attributed to inheritance practices: daughters traditionally inherit the family home and farm, whereas the sons are expected to move to their wives' homes after marriage (UNESCO 2008). However, it was not unusual for the husband to serve as the CFMG member, even when he was living in his wife's home - the respondents explained that the choice of who would serve as member depended largely on personal interest. There was no consistent explanation for the higher number of male members in Masangdaza CF, and no observable differences between the three CFs in terms of forest management gender roles. Gender analysis of issues related to personal knowledge, such as knowledge about the CF Fund, was based on the gender of the actual respondent. Gender analysis of household issues, such as the utilization of forest products, was based on the gender of the actual member.

The results of the household survey were analyzed using SPSS Version 15.0. Data sets with normal distributions were analyzed for group differences using the One Way ANOVA $(F)$ or Independent t-test $(t)$. Data sets with non-normal distributions were analyzed for group differences using Kruskal-Wallis $(H)$ and Mann Whitney $(U)$, for correlations using Kendal's tau $(\tau)$, for cross tabulations and odds ratios $(O R)$ using Pearson Chi-square $\left(\chi^{2}\right)$, for repeated measures data using Wilcoxon Signed Ranks $(T)$, and for trends using the Jonckheere-Terpstra $(J)$. All reported results were twosided and significant with a probability of $p \leq .05$. Statistical results with means $(M)$ and medians (Mdn) are included in Table 3, and are referenced in the text by lower case letters in parentheses after each comparison.

A second important source of quantitative data was the lists of permits issued in the three CFs during the first three years of harvesting operations. This information was available for $100 \%$ of the members of the three CFMGs, so statistical analysis was not required. The same four socio-economic categories were used for the analysis of the permits. The household survey verified that the permit recipients actually received the trees.

A series of focus group meetings was conducted by the authors during March-June 2005 to solicit inputs from residents of neighbouring villages who were not included in the CFs. Other qualitative information was collected through in-depth interviews with key informants such as government extension agents and teachers. The study also utilized data from interviews conducted by the authors over the previous five year period, which started before the formal approval of the management plans and continued throughout the first three years of forest management in all three CFs.

TABLE 2 CMFG members by socio-economic group of household and gender

\begin{tabular}{|c|c|c|c|c|c|c|c|c|c|}
\hline & & \multicolumn{2}{|c|}{ All Studied CFs } & \multicolumn{2}{|c|}{ Yakpugang CF } & \multicolumn{2}{|c|}{ Masangdaza CF } & \multicolumn{2}{|c|}{ Shambayung CF } \\
\hline & & Number & Percent & Number & Percent & Number & Percent & Number & Percent \\
\hline \multirow{4}{*}{$\begin{array}{l}\text { Socio-economic } \\
\text { group of } \\
\text { household }\end{array}$} & Labourer & 47 & 27 & 31 & 27 & 6 & 16 & 10 & 44 \\
\hline & Small Farmer & 56 & 32 & 31 & 27 & 20 & 54 & 5 & 22 \\
\hline & Large Farmer & 53 & 31 & 40 & 35 & 8 & 22 & 5 & 22 \\
\hline & Salary Earner & 17 & 10 & 11 & 10 & 3 & 8 & 3 & 13 \\
\hline \multirow{3}{*}{$\begin{array}{l}\text { Gender of } \\
\text { CFMG Member }\end{array}$} & Female & 88 & 51 & 56 & 50 & 14 & 38 & 18 & 78 \\
\hline & Male & 85 & 49 & 57 & 50 & 23 & 62 & 5 & 22 \\
\hline & Total & 173 & 100 & 113 & 100 & 37 & 100 & 23 & 100 \\
\hline
\end{tabular}




\section{FINDINGS}

\section{Economic equity}

The poorest $\mathrm{CF}$ households received a greater number of timber trees per household than the richer households (figure 2). The same applied to female members in comparison to male members (figure 3). Committee members received approximately the same number of timber trees per household as regular members (figure 4). These

FIGURE 2 Number of trees received per household by socio-economic group in studied CFs

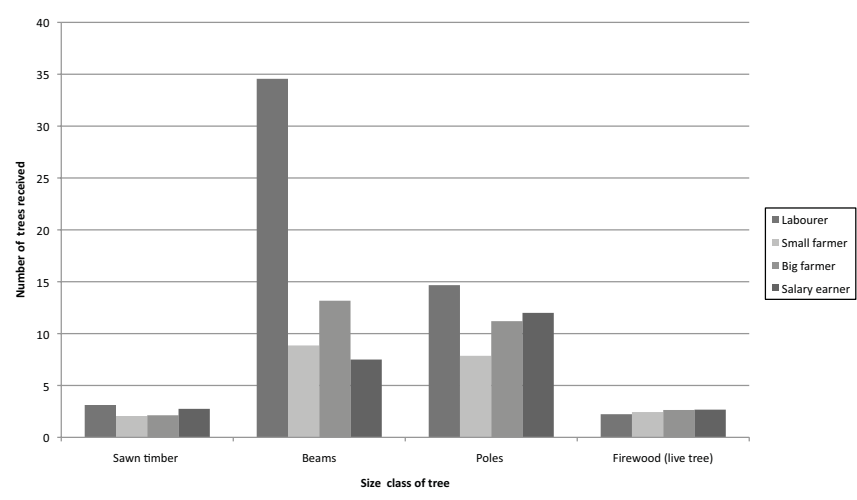

FIGURE 3 Number of trees received per household by gender of CFMG member in studied community forests

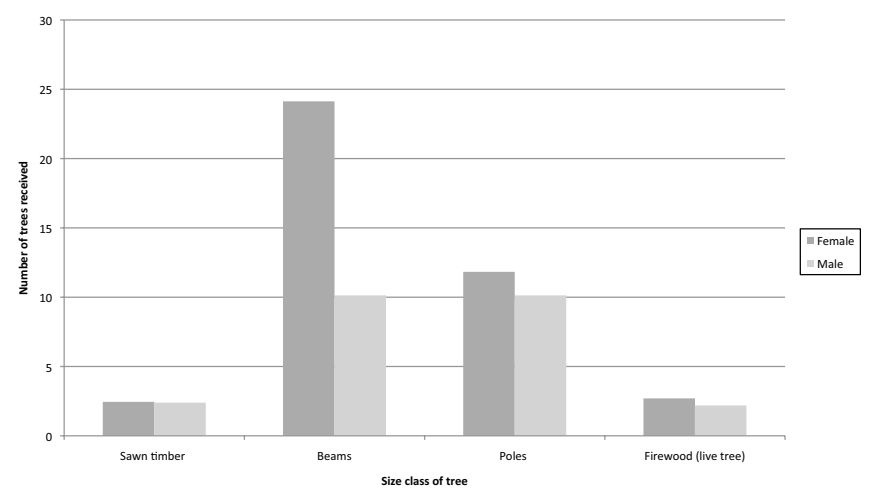

FIGURE 4 Number of trees received by houshold by committee members and regular members in studied community forest

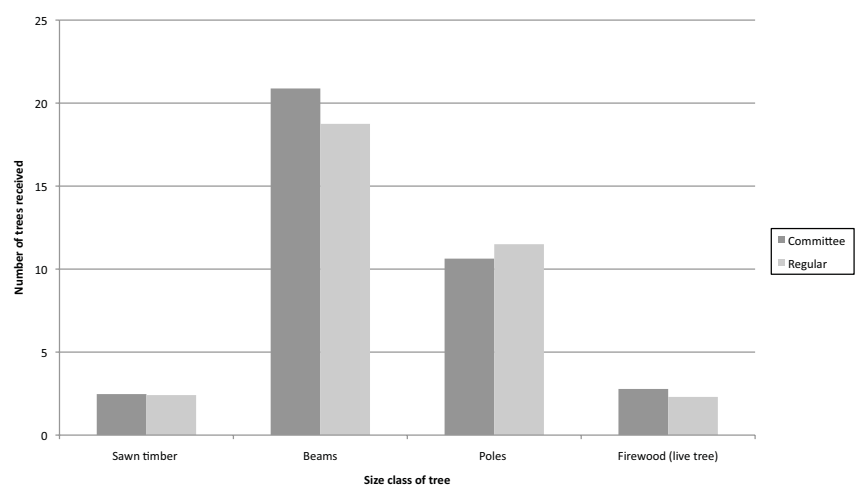

indicators are significant because timber was considered by all respondents to be the most important product from the $\mathrm{CF}$. These trends were generally consistent in the individual CFs (table 4). The poorest households and female members were also more likely to receive timber trees than other members (table 5). The only indication of inequity was that committee members were more likely to receive timber trees than regular members (table 5), despite receiving the same number of trees per household as the regular members (figure 4). There were no indications that richer members were given preference regarding the location of trees for harvesting: the average time to reach a marked tree from the home of the recipient was 56 minutes for timber trees and 42 minutes for firewood trees, with no significant differences between the socio-economic groups or between male and female members in any of the CFs.

Dry firewood, which could be collected without a permit or payment, was collected by $94 \%$ of the respondents. There were no significant differences between the socio-economic groups in the amount of dry firewood collected inside the CF. However, female respondents were significantly more likely to harvest dry firewood inside the $\mathrm{CF}$ than males (table 3, row a) and collected significantly more headloads of firewood inside the $\mathrm{CF}$ than males (table 3, row b). This was consistent with the finding described below that women were interested in a broader range of CF products than men, who were more focused on the timber resources.

Almost all households owned and grazed livestock in the CFs or in other national forests. The average livestock holdings per household decreased significantly between 2000 and 2005 (table 3, row c), with $70 \%$ of the respondents reporting decreased holdings. The general trend was to replace local cattle with smaller numbers of improved breeds (table 3, rows d, e), which reduced the number of animals grazing inside the $\mathrm{CF}$ because the improved breeds were generally grazed on private land rather than in the CFs (table 3 , row $f, g$ ). There were no significant differences between male and female members in terms of livestock holdings or use of the $\mathrm{CF}$ for grazing. The wealthier socio-economic groups tended to own more livestock than the poorer groups (table 3, row h) and graze more livestock inside the CF (table 3 , row i). However, the establishment of the CF did not appear to impact the grazing location of various socio-economic groups differently: there were no significant differences between the socio-economic groups in terms of changes in the percentage of household livestock grazing inside the $\mathrm{CF}$ before and after the establishment of the CF.

Most households (65\%) collected NWFPs such as ferns, mushrooms, wild vegetables and bamboo inside the CFs $(35 \%)$ or in other national forests $(42 \%)$. Only $12 \%$ of the households sold NWFPs collected from the CF, and none reported this as a major source of income. None of the socioeconomic groups were more likely than others to collect or sell NWFPs from the CFs, and there were no significant differences between male and female members. 
TABLE 3 Statistically significant results from household survey

\begin{tabular}{|c|c|c|}
\hline Tes & & Results \\
\hline a & $\begin{array}{l}\text { Likelihood of female vs. male respondents collecting dry } \\
\text { firewood inside the CFs }\end{array}$ & $\chi^{2}(1)=8.79, p<.01$, OR 6.25 \\
\hline $\mathrm{b}$ & $\begin{array}{l}\text { Comparison of } \mathrm{N} \text { headloads dry firewood collected inside } \\
\text { CFs by female vs. male members. }\end{array}$ & $\begin{array}{l}\text { Females }(M d n=4, M=5.94), \text { males }(M d n=0, M=2.11), U \\
=338.5, p<.01, r=.37\end{array}$ \\
\hline $\mathrm{c}$ & $\begin{array}{l}\text { Comparison of livestock holdings per household between } \\
2000 \text { and } 2005\end{array}$ & $\begin{array}{l}2000(M d n=7, M=8.43), 2005(M d n=4, M=.26) T= \\
125.50, p<.001\end{array}$ \\
\hline d & $\begin{array}{l}\text { Comparison of livestock holdings per household between } \\
2000 \text { and } 2005 \text { (Yakpugang CF) }\end{array}$ & $\begin{array}{l}2000(M d n=7, M=7.11), 2005(M d n=3, M=3.76) T= \\
38.00, p<.001\end{array}$ \\
\hline $\mathrm{e}$ & $\begin{array}{l}\text { Comparison of livestock holdings per household between } \\
2000 \text { and } 2005 \text { (Masangdaza CF) }\end{array}$ & $\begin{array}{l}2000(M d n=11, M=12.45), 2005(M d n=6, M=7.83) T= \\
3.25, p<.05\end{array}$ \\
\hline $\mathrm{f}$ & $\begin{array}{l}\text { Comparison of number of livestock grazing in the CFs } \\
\text { between } 2000 \text { and } 2005\end{array}$ & $\begin{array}{l}2000(M d n=2, M=3.6), 2005(M d n=0, M=1.3) T=19.00, \\
p<.001\end{array}$ \\
\hline $\mathrm{g}$ & $\begin{array}{l}\text { Comparison of number of livestock grazing on private land } \\
\text { between } 2000 \text { and } 2005\end{array}$ & $\begin{array}{l}2000(M d n=4, M=4.4), 2005(M d n=0, M=2.5) T=28, \\
p<.001\end{array}$ \\
\hline $\mathrm{h}$ & $\begin{array}{l}\text { Increasing trend of livestock holdings per household in } 2005 \\
\text { by socioeconomic group }\end{array}$ & $\begin{array}{l}\text { Labourers }(M d n=3) \text { small farmers }(M d n=4) \text { large farmers } \\
(M d n=4) \text { salary earners }(M d n=11), J(3)=623, p<.01\end{array}$ \\
\hline $\mathrm{i}$ & $\begin{array}{l}\text { Increasing trend of number of livestock per household } \\
\text { grazing in the CFs in } 2005 \text { by socioeconomic group }\end{array}$ & $\begin{array}{l}\text { Labourers }(M d n=0) \text { small farmers }(M d n=0) \text { large farmers } \\
(M d n=1) \text { salary earners }(M d n=2), J(3)=572, p<.05\end{array}$ \\
\hline $\mathrm{j}$ & $\begin{array}{l}\text { Likelihood of female vs. male respondents considering future } \\
\text { access to all forest products as the primary future benefit of } \\
\text { the CFs rather than focusing exclusively on timber }\end{array}$ & $\chi^{2}(1)=9.63, p<.01$, OR 5.4 \\
\hline
\end{tabular}

TABLE 4 Average number trees per recipient by socio-economic group, membership status and gender

\begin{tabular}{|c|c|c|c|c|c|c|c|c|c|}
\hline \multirow{3}{*}{$\mathrm{CF}$} & \multirow{3}{*}{$\begin{array}{l}\text { Size } \\
\text { class }\end{array}$} & \multicolumn{8}{|c|}{ Average number trees per recipient } \\
\hline & & \multicolumn{4}{|c|}{ Socio-economic Group } & \multicolumn{2}{|c|}{ Membership status } & \multicolumn{2}{|c|}{ Gender } \\
\hline & & Labourer & $\begin{array}{l}\text { Small } \\
\text { farmer }\end{array}$ & $\begin{array}{l}\text { Large } \\
\text { farmer }\end{array}$ & $\begin{array}{l}\text { Salary } \\
\text { earner }\end{array}$ & Committee & Regular & $\mathrm{F}$ & M \\
\hline \multirow{4}{*}{ All CFs } & Sawn timber & 3.12 & 2.06 & 2.13 & 2.75 & 2.47 & 2.41 & 2.45 & 2.39 \\
\hline & Beams & 34.56 & 8.86 & 13.17 & 7.50 & 20.88 & 18.75 & 24.13 & 10.13 \\
\hline & Poles & 14.67 & 7.86 & 11.20 & 12.00 & 10.63 & 11.50 & 11.83 & 10.13 \\
\hline & Firewood & 2.23 & 2.44 & 2.64 & 2.67 & 2.78 & 2.30 & 2.70 & 2.19 \\
\hline \multirow{4}{*}{ Yakpugang } & Sawn timber & 3.88 & 2.56 & 2.24 & 1.67 & 2.67 & 2.61 & 2.65 & 2.60 \\
\hline & Beams & 0 & 0 & 0 & 0 & 0 & 0 & 0 & 0 \\
\hline & Poles & 0 & 0 & 0 & 0 & 0 & 0 & 0 & 0 \\
\hline & Firewood & 1.36 & 2.00 & 2.13 & 3.60 & 1.92 & 2.15 & 2.00 & 2.13 \\
\hline \multirow{4}{*}{ Masangdaza } & Sawn timber & 1.00 & 1.00 & 1.00 & 0 & 1.00 & 1.00 & 1.00 & 1.00 \\
\hline & Beams & 2.00 & 5.67 & 2.00 & 0 & 0 & 4.20 & 2.00 & 4.75 \\
\hline & Poles & 8.50 & 6.00 & 5.00 & 0 & 1.00 & 7.14 & 7.33 & 5.80 \\
\hline & Firewood & 1.00 & 1.33 & 2.00 & 1.00 & 2.00 & 1.29 & 1.20 & 1.67 \\
\hline \multirow{4}{*}{ Shambayung } & Sawn timber & 2.63 & 2.00 & 2.20 & 6.00 & 2.43 & 2.70 & 2.54 & 2.75 \\
\hline & Beams & 38.63 & 11.25 & 15.40 & 7.50 & 20.88 & 25.36 & 25.60 & 15.50 \\
\hline & Poles & 17.75 & 10.33 & 15.33 & 12.00 & 12.00 & 17.60 & 12.33 & 17.33 \\
\hline & Firewood & 3.56 & 3.80 & 4.40 & 1.67 & 3.90 & 3.25 & 3.76 & 2.80 \\
\hline
\end{tabular}

Note: Data are from permit records of all CFMG members, so statistical analysis is not required. 
TABLE 5 Percent of members receiving permits for timber and firewood by socio-economic group, status, sex)

\begin{tabular}{|c|c|c|c|c|c|c|c|c|c|}
\hline \multirow{3}{*}{$\mathrm{CF}$} & \multirow{3}{*}{ Size Class } & \multicolumn{8}{|c|}{$\%$ members in each category receiving permits } \\
\hline & & \multicolumn{4}{|c|}{ Socio-economic Group } & \multicolumn{2}{|c|}{ Membership Status } & \multicolumn{2}{|c|}{ Sex } \\
\hline & & Labourer & $\begin{array}{c}\text { Small } \\
\text { farmer }\end{array}$ & $\begin{array}{l}\text { Large } \\
\text { farmer }\end{array}$ & $\begin{array}{l}\text { Salary } \\
\text { earner }\end{array}$ & Committee & Regular & $\mathrm{F}$ & M \\
\hline \multirow{4}{*}{ All CFs } & Sawn timber & 36 & 29 & 45 & 24 & 45 & 33 & 38 & 33 \\
\hline & Beams & 19 & 13 & 11 & 12 & 21 & 12 & 18 & 9 \\
\hline & Poles & 13 & 13 & 9 & 12 & 21 & 9 & 14 & 9 \\
\hline & Firewood & 47 & 29 & 42 & 53 & 33 & 68 & 42 & 38 \\
\hline \multirow{4}{*}{ Yakpugang } & Sawn timber & 26 & 29 & 43 & 27 & 38 & 32 & 30 & 35 \\
\hline & Beams & 0 & 0 & 0 & 0 & 0 & 0 & 0 & 0 \\
\hline & Poles & 0 & 0 & 0 & 0 & 0 & 0 & 0 & 0 \\
\hline & Firewood & 36 & 26 & 38 & 46 & 69 & 31 & 27 & 42 \\
\hline \multirow{4}{*}{ Masangdaza } & Sawn timber & 17 & 20 & 25 & 0 & 25 & 18 & 21 & 17 \\
\hline & Beams & 17 & 15 & 13 & 0 & 0 & 15 & 7 & 17 \\
\hline & Poles & 33 & 20 & 25 & 0 & 25 & 21 & 21 & 22 \\
\hline & Firewood & 33 & 15 & 25 & 33 & 13 & 55 & 36 & 13 \\
\hline \multirow{4}{*}{ Shambayung } & Sawn timber & 80 & 60 & 100 & 33 & 70 & 77 & 72 & 80 \\
\hline & Beams & 80 & 80 & 100 & 67 & 80 & 85 & 83 & 80 \\
\hline & Poles & 40 & 60 & 60 & 67 & 70 & 38 & 50 & 60 \\
\hline & Firewood & 90 & 100 & 100 & 100 & 33 & 68 & 94 & 100 \\
\hline
\end{tabular}

Note: Data are from permit records of all CFMG members, so statistical analysis is not required.

TABLE 6 Representation on management committee by socio-economic group and sex

\begin{tabular}{|c|c|c|c|c|c|c|c|}
\hline & & \multicolumn{4}{|c|}{ Socio Economic Group } & \multicolumn{2}{|c|}{ Sex } \\
\hline & & Labourer & $\begin{array}{c}\text { Small } \\
\text { Farmer }\end{array}$ & $\begin{array}{l}\text { Large } \\
\text { Farmer }\end{array}$ & $\begin{array}{l}\text { Salary } \\
\text { Earner }\end{array}$ & $\mathrm{F}$ & M \\
\hline \multirow{2}{*}{ All CFs } & $\%$ of committee & 18 & 32 & 42 & 8 & 58 & 42 \\
\hline & $\%$ of all members & 27 & 32 & 31 & 10 & 51 & 49 \\
\hline \multirow{2}{*}{ Yakpugang CF } & $\%$ of committee & 13 & 33 & 46 & 8 & 58 & 42 \\
\hline & $\%$ of all members & 27 & 27 & 35 & 10 & 50 & 50 \\
\hline \multirow{2}{*}{ Masangdaza CF } & $\%$ of committee & 0 & 50 & 50 & 0 & 25 & 75 \\
\hline & $\%$ of all members & 16 & 54 & 22 & 8 & 38 & 62 \\
\hline \multirow{2}{*}{ Shambayung CF } & $\%$ of committee & 40 & 20 & 30 & 10 & 70 & 30 \\
\hline & $\%$ of all members & 44 & 22 & 22 & 13 & 78 & 22 \\
\hline
\end{tabular}

Note: Data are from all CFMG members, so statistical analysis is not required.

\section{Political equity}

The management committees of all three CFs included a mix of rich and poor households, although the poorest group tended to be under-represented, filling only $18 \%$ of the committee positions despite representing $27 \%$ of the all members (table 6). Several respondents from the poorest group explained that they could not serve on the committee because of their long absences form the village for seasonal labour. Women held $58 \%$ of the committee positions, however the powerful positions of chairman and secretary were always held by men.

Attendance at $\mathrm{CF}$ meetings was high: $80 \%$ of the households had participated in the previous meeting However, the overall level of knowledge of CFMG administration was low: only $18 \%$ of the respondents knew how much money was currently in the $\mathrm{CF}$ fund or could explain how the fund was intended to be used. There were no significant differences in attendance at CF meetings or knowledge of CFMG administration between the socio-economic groups or male and female members in any of the CFs.

The respondents consistently responded that the CFMG management and distribution of benefits was fair, even though $31 \%$ reported that their household had not yet benefited directly from the CF. Informal discussions with CFMG members confirmed that the current system of equal contributions and equal benefits was considered to be fair. Almost all of the respondents $(96 \%)$ could explain how 
they expected to benefit from the CFs in the future. Most respondents $(60 \%)$ mentioned simplification of the process for obtaining timber permits as the major benefit of the CF. Only one respondent reported difficulty in meeting the requirements for contributing voluntary labour. Female respondents were more likely to consider future access to all forest products as the primary future benefit of the $\mathrm{CF}$, whereas males were more likely to focus exclusively on timber (table 3, row j). There were no significant differences between the socio-economic groups in any of the CFs in relation to past or anticipated benefits.

\section{DISCUSSION}

The first research question asked whether the equity problems documented in neighbouring countries were also emerging in Bhutan. The findings indicate a relatively high level of economic equity. The poorest CFMG households in Bhutan received more timber than other households, whereas the opposite has been reported in Nepal (Chhetry et al. 2005, Maharjan et al. 2009, Malla et al. 2003, Nightingale 2003). This is important because most households, both rich and poor, considered timber to be the most important CF product. The fact that poorer households were able to obtain more timber than richer households indicates that the cost of the permits was not a deterrent, whereas Schreckenberg and Luttrell (2009) have reported that often only richer members have financial resources to benefit fully from their CFs. Female members also received more timber from the $\mathrm{CF}$ more than male members, contrary to some findings in Nepal (Adhikari 2005). Although committee members were more likely to receive timber than regular members, they receive approximately the same number of trees per household.

In fact the distribution of timber appeared to favour the poorer and female members, even though there were no related provisions in the management plans. Several richer members mentioned that they had postponed requesting timber to repair their existing houses because they knew that some poorer and female members had more urgent needs. Influential members did not enjoy special grazing privileges, as has reported in Nepal (Pandit and Thapa 2004), and even though the richer farmers owned more cattle and thus used the CF more for grazing, there were no indications that the establishment of the CF had any negative impact on the livestock management practices of the poorer households in terms of the location of grazing. Furthermore, there were no indications that management committees practiced favouritism in distributing products, as reported in Nepal (Springate-Baginski et al. 2003, Varalakshmi 2002). Thus the sharing of benefits in the CFs appeared to be relatively equitable in terms of access to products, and more importantly in terms of the local perception of fairness as described by Poteete (2004): both rich and poor villagers consistently told us that the distribution of CF products was fair.

The level of political equity was less impressive, but higher than most reports from neighbouring countries. Poor households were generally well represented in the management committees, attended CF meetings, and knew as much about the $\mathrm{CF}$ finances as other households. The representation of poorer households may have had an impact on establishing a fee structure for forest permits that does not discourage utilization by poorer members. This contrasts with the situation in Nepal and India, where management committees were often been found to be dominated by men and high caste groups (Kellert et al. 2000), although there are recent indications of increasing representation of disadvantaged groups (Maharjan et al. 2009).

Female members in Bhutan attended CF meetings and had as much knowledge of CF administration as men, and were more likely than men to represent their households in the CFMG. However their influence in the CF management committees was limited, as they consistently held junior committee positions rather than the key positions of chairman and secretary. The literacy requirement for committee members appears to have a negative impact in this regard, as the literate women in the villages tended to be young unmarried women who had limited influence in the community. Despite their positions on the CFMG committees, they appeared to be less confident, outspoken or knowledgeable about forest management issues than the older illiterate women. Thus there is certainly considerable potential for increasing the role of women in the $\mathrm{CF}$ management in Bhutan, but the involvement of women in CFs in Bhutan compares favourably with Nepal and India, where it has been reported that women in some CFs rarely attend CF meetings (Springate-Baginski et al. 2003) and are excluded from decision making (Agarwal 2001).

The high level of ethnic homogeneity in Bhutan may have influenced equity in the studied CFs. Many scholars believe that homogeneity is needed to initiate and sustain self governance, because ethically diverse groups may not have a common understating of their situation and may not trust each other to keep promises (Dongal 2005, Ostrom 1999). Each of the three studied villages was ethnically homogenous, and the residents shared a common language and did not observe the caste system. The study documented participation in several communal livelihood activities such as gathering firewood and caring for livestock, as well as regular participation in religious events. Social relations are important in Bhutan, and the sense of well-being is closely linked to the perceived availability of social support (Choden 2007). In contrast, several authors have reported that ethnic heterogeneity in CFMGs in Nepal contributes to inequity (Adhikari 2005, Malla et al 2003, Uprety 2006). Buffum and Chettri (2000) noted that some ethnically homogenous CFMGs in Nepal had more effective systems for distributing CF products than ethnically heterogeneous CFs in the same district.

A second factor affecting equity may have been the active participation of women. Agrawal and Chhatre (2006) reported that involvement of women in decision making was associated with improved forest condition, because women could make sound management decisions based on knowledge gained through collection of forest products. In the Bhutan study, more than half $(51 \%)$ of the members of the CFs were female, and the women attended CF meetings 
as regularly as men. The female respondents in the household survey had strong views on forest management and were very comfortable expressing their views during group meetings. This supports findings from other studies which found that Bhutanese women interact freely with male extensionists and are actively involved in forestry issues (Duba et al 1998, Namgay and Sonam 2006, TFDP 2000). In Nepal, cultural norms discouraged women from participating in CF meetings (Springate-Baginski et al. 2003), and female membership in studied CFMGs in Nepal and India was only $3.5 \%$ and $10 \%$ respectively (Agrawal and Ostrom 2001).

A third factor affecting equity may have been supportive government policy. Ostrom (1999) found that the CFs of successful CFMGs tend to be neither so degraded that it is useless for the CFMG to organize nor so underutilized that there is little advantage from organizing Bhutan's community forestry policy stipulates that CFs should be approximately $50 \%$ well-stocked and $50 \%$ degraded in order to both provide immediate benefits and improve the quality of the forest (MOA 2003. The three studied CFs had these attributes: they were well stocked enough to allow immediate timber harvesting, yet many CFMG members expressed the view that the forests would have become degraded over time without effective management. Bhutan's policy of handing over well-stocked forests for community forestry is unusual: governments in many countries have only been willing to hand over degraded forests for community management (Carter 2005, Menzies 2002, Hobley 2005). Forest policies in Nepal since 2000 have restricted the handover of well-stocked forests in the Terai/ Churia regions while continuing to promote the handover of relatively low value forests in the mid-hills hills (Agrawal and Ostrom 2001, Bhattarai 2006). The Indian government retained control of the most productive forest land and allocated fragmented and degraded patches for community management (Agrawal and Ostrom 2001).

A fourth factor affecting equity may have been effective and intensive forestry extension, which many authors believe is critical in community forestry programs (Agrawal and Gupta 2005, Menzies 2002, Nurse et al. 2004). The three CFMGs in Bhutan received intensive extension support: the extension agents responsible for the studied CFs lived within a few $\mathrm{km}$ of the sites, had regular contact with the CFMGs, and knew many CFMG members by name. After the approval of the CFs, they worked closely with the management committees to develop systems to monitor compliance with the utilization rules, a skill which has been identified as crucial for successful CF management (Gibson et al 2005). In Bhutan, forestry extensionists are trained separately from other foresters and work under the jurisdiction of the district administration, whereas other foresters are managed centrally by the DOF. This may reduce the incongruence between the "hierarchical working culture of state forestry agencies and the decentralized working ethos of (community based forest management) systems' prevalent in many countries (Kumar and Kant 2005: 652). In contrast, it has been reported in Nepal that forestry staff 'seem to have little concern or understanding of the ways in which committee members distribute forest products and control access to forest products' (Malla et al 2003: 88).

In conclusion, there were few indications of emerging problems with economic and political equity after three years of $\mathrm{CF}$ operations. We hypothesise that these unexpected findings can be attributed to four factors: ethnic homogeneity, active participation of women, supportive government policy and intensive extension support. These factors appear to have given the CFMGs many of the attributes of successful CFMGs identified by Ostrom (1999). These findings are important because governments can directly affect most of these factors, implying that equity in other countries could be enhanced by appropriate community forestry policies and programs. Furthermore, some authors argue that equity and improved forest management are linked: a study of 95 $\mathrm{CFs}$ in the Indian Himalayas found that improved forest condition was associated with reduced levels of conflict and greater involvement of women in decision making (Agrawal and Chhatre 2006).

This was the first study of its kind in Bhutan, and the conclusions are preliminary due to the small number of CFs with harvesting experience at the time of the study. However, Bhutan's experience with community forestry is rapidly expanding. Many other CFMGs have started harvesting operations since the fieldwork for this study was completed, including some that are ethnically heterogeneous. Another study of an expanded number of CFs over a longer time period would provide greater understanding of the factors affecting equity in community forestry.

\section{NOTES}

1. This report uses the terminology of Bhutan, in which the members of a community forest user group are referred to as community forestry management groups. In Nepal, they are usually referred to as community forest user groups; in India as village forest committees or joint forest management committees.

2. See DOF (2004) for details on the CF planning and implementation process.

\section{ACKNOWLEDGEMENTS}

This research was conducted with inputs from many staff members of the Ministry of Agriculture of Bhutan and other agencies. Special thanks to Yeshi Tenzin, Shacha Dorji, Namkha Gyeltshen, Georg Gratzer, Michael Pregernig, Andras Darabant, the management committees of the studied community forests, and the anonymous reviewers. Funding for the research was provided by the Swiss Agency for Development and Cooperation (SDC) and Helvetas.

\section{REFERENCES}

ADHIKARI, B. 2005. Poverty, property rights and collective action: understanding the distributive aspects of common 
property resource management. Environment and Development Economics 10: 7-31.

AGARWAL, B. 2001. Participatory exclusions, community forestry, and gender: an analysis for South Asia and a conceptual framework. World Development 29 (10): 1623-1648.

AGRAWAL, A and CHHATRE, A. 2006. Explaining success on the commons: community forest governance in the Indian Himalaya. World Development 34 (1): 149-166.

AGRAWAL, A. and GUPTA, K. 2005. Decentralization and participation: The governance of common pool resources in Nepal's Terai. World Development 33 (7): 1101-1114.

AGRAWAL, A. and OSTROM, E. 2001. Collective action, property rights, and decentralization in resource use in India and Nepal. Politics \& Society 29 (4): 485-514.

ANAND, S. and SEN, A. K. 1996. Sustainable human development: concepts and priorities, Office of Development Studies Discussion Paper Series No. 1. New York, United Nations Development Programme.

BACALLA, D.T. 2006. Promoting equity: a challenge in the implementation of community-based forest management strategy in the Philippines. In: MAHANTY, S., FOX, J., NURSE, M., STEPHEN, P. and MCLEES, L. (eds.) Hanging in the Balance: Equity in Community-Based Natural Resource Management in Asia. Bangkok, RECOFTC and East-West Center.

BHATTARAI, B. 2006. Widening the gap between Terai and hill farmers in Nepal: The Implications of the New Forest Policy 2000. In: MAHANTY, S., FOX, J., NURSE, M., STEPHEN, P. and MCLEES, L. (eds.) Hanging in the Balance: Equity in Community-Based Natural Resource Management in Asia. Bangkok, RECOFTC and EastWest Center.

BUFFUM, B. and CHETTRI, R. 2000. Post-Project Evaluation of Begnas Tal/Rupa Tal Watershed Management Project. Kathmandu, CARE Nepal.

BUFFUM, B., GRATZER G., TENZIN Y. 2008. The Sustainability of Selection Cutting in a Late Successional Broadleaved Community Forest in Bhutan. Forest Ecology and Management 256: 2084-2091

BUFFUM, B., GRATZER G., TENZIN Y. 2009. Forest Grazing and Natural Regeneration in a Late Successional Broadleaved Community Forest in Bhutan. Mountain Research and Development 29(1): 30-35.

CARTER, J. 2005. Recent Experience in Collaborative Management - CIFOR Occasional Paper No. 43. Bogor, Centre for International Forestry Research.

CHHETRY, B., FRANCIS, P., GURUNG, M., IVERSEN, V., KAFLE, G., PAIN, A. and SEELY, J. 2005. A Framework for the analysis of community forestry performance in the Terai. Journal of Forest and Livelihood 4 (2): 1-16.

CHODEN, T. 2007. Gross National Happiness and Material Welfare in Bhutan and Japan. Thimphu, Centre for Bhutan Studies.

CIA. 2007. Bhutan - The World Factbook. Washington, Central Intelligence Agency.

CRONKLETON, P., LEIGH TAYLOR, P. L., BARRY, D., STONE-JOVICICH, S. and SCHMINK, M. 2008.
Environmental Governance and the Emergence of ForestBased Social Movements. CIFOR Occasional Paper No. 49. Jakarta, Center for International Forestry Research.

DOF. 2004. Community Forestry Manual for Bhutan. Thimphu, Social Forestry Division, Department of Forests, Ministry of Agriculture, Royal Government of Bhutan.

DONGAL, S. (2005). Participation and Decisionmaking in Nepal, in COLVER, CJP (ed) The Equitable Forest - Diversity, Community and Resource Management. Washington DC: Resources for the Future.

DUBA, S., URBAN, R. and WANGCHUK, D. (eds.) 1998. Participatory Forest Management for Local Use: Report of a Participatory Rural Appraisal of Forest Resources and Forest Management in the Lingmutey Chhu Watershed, No. 41. Wangdue-Phodrang, Bhutan-German Sustainable RNR Development Project, GTZ/Ministry of Agriculture, Royal Government of Bhutan.

GAUTAM, C. M., and WATANABE, T. 2004. Reliability of land use/land cover assessment in Montane Nepal - a case study in the Kangchenjunga Conservation Area (KCA). Mountain Research and Development 24 (1): 35-43.

GIBSON, C. C., WILLIAMS, J. T. and OSTROM, E. 2005. Local enforcement and better forests. World Development 33 (2): 273-284.

HOBLEY, M. 2005. Building state-people relationships in forestry. In: Forest Policy and Environment Programme: Grey Literature. London, Forest Policy and Environment Programme, Overseas Development Institute.

KELLERT, S. R., MEHTA, J. N., EBBIN, S. A. and LICHTENFELD, L. L. 2000. Community natural resource management: promise, rhetoric, and reality. Society \& Natural Resources 13 (8): 705-715.

KUMAR, S. and KANT, S. 2005. Bureaucracy and new management paradigms: modelling foresters' perceptions regarding community-based forest management in India. Forest Policy and Economics 7 (4): 651-669.

LAWRENCE, A. 2007. Beyond the second generation: towards adaptiveness in participatory forest management. $C A B$ Reviews: Perspectives in Agriculture, Veterinary Science, Nutrition and Natural Resources 2, available at www.cababstractsplus.org/cabreviews

MAHANTY, S., FOX, J., MCLEES, L., NURSE, M. and STEPHEN, P. 2006. Equity in community-based resource management. In: MAHANTY, S., FOX, J., NURSE, M., STEPHEN, P. and MCLEES, L. (eds.) Hanging in the Balance: Equity in Community-Based Natural Resource Management in Asia. Bangkok, RECOFTC and EastWest Center.

MAHARJAN, M. R., DHAKAL, T.R., THAPA, S.K., SCHRECKENBERG, K. and LUTTRELL, C. 2009. Improving the benefits to the poor from community forestry in the Churia region of Nepal. International Forestry Review 11(2): 254-257

MAHARJAN, M. R. 2001. Yield Regulation Techniques for Community Forest Management in Nepal: Opportunities and Constraints. In: VICTOR, M. and BARASH, A. (eds.) Cultivating Forests - Alternative Forest Management 
Practices and Techniques for Community Forestry. Bangkok, RECOFTC.

MALLA, Y., NEUPANE, H. R. and BRANNEY, P. J. 2003. Why aren't poor people benefiting more from community forestry? Journal of Forest and Livelihood 3 (1): 78-90.

MCDERMOTT, M. H. AND SCHRECKENBERG, K. 2009. Equity in community forestry: insights from North and South. International Forestry Review 11(2): 157-171

MCKEAN, M. A. 2000. Common property: what is it, what is it good for, and what makes it work? In: Gibson, C. C., MCKEAN, M. A. and OSTROM, E. (eds.) People and forests: communities, institutions, and governance. Cambridge, Mass, MIT Press.

MENZIES, N. K. 2002. Global gleanings lessons from six studies of community based forest management, Report for Ford Foundation's Environment and Development Affinity Group (EDAG). Berkley, Ford Foundation.

MOA. 2003. Forest and Nature Conservation Rules 2003. Thimphu, Ministry of Agriculture, Royal Government of Bhutan.

MYERS, N., MITTERMEIER, R. A., MITTERMEIER, C. G., DA FONSECA, G. A. B. and KENT, J. (2000). Biodiversity hotspots for conservation priorities. Nature 403(6772): 853-858.

NAMGAY, K., and T. SONAM. 2006. Gender and equity: a challenge in community forestry, In: A Series of Case Studies on Community Based Forest and Natural Resource Management in Bhutan. Thimphu, Ministry of Agriculture, Royal Government of Bhutan.

NIGHTINGALE, A. 2003. Nature-society and development: social, cultural and ecological change in Nepal. Geoforum 34 (4): 525-540.

NURSE, M., ROBINSON, P., PAUDEL, D. and POKHAREL, B. 2004. Towards pro-poor community forestry - recent experiences from Dolakha and Okhaldunga Districts. In: TIMSINA, N. P. and OJHA, H. R. (eds.) Case Studies on Equity and Poverty in the Management of Common Property Resources in Nepal. Kathmandu, Forest Action.

OBERHOLZER, E., BUFFUM, B., KINLEY and DHONO. 2003. Forest Management by Bhutanese Villagers: Experience to Date of the Community Forestry Program. Thimphu, Participatory Forest Management Project, Helvetas/SDC/Department of Forests, Ministry of Agriculture, Royal Government of Bhutan.

OSTROM, E. 1999. Self-governance and forest resources. CIFOR Occasional Paper No. 20. Jakarta, CIFOR.

PANDIT, B. H, and THAPA, G. B. 2004. Poverty and resource degradation under different common forest resource management systems in the mountains of Nepal. Society and Natural Resources 17: 1-16.

PENJORE, D., and RAPTEN, P. 2004. Trends of forestry policy concerning local participation in Bhutan. In: HARADA, K. and KANAGAWA, M. N. (eds.) Policy Trend Report 2004. Institute for Global Environmental Strategies.

POKHAREL, B., and NURSE, M. 2004. Forest and people's livelihood: benefiting the poor from community forestry. Journal of Forest and Livelihood 4 (1): 19-30.
POMMARET, F.. 1991. Bhutan. Lincolnwood, Ill; Passport Books.

POTEETE, A. R. 2004. Is decentralization a reliable means of increasing equity? Paper presented at the Tenth Biennial Conference of the International Association for the Study of Common Property (IASCP), 9-13 August 2004, Oaxaca, Mexico.

RGOB (2005). Results of Population and Housing Census of Bhutan 2005. Thimphu: Office of Census Commissioner, Royal Government of Bhutan.

SAKURAI, T., RAYAMAJHI, S., POKHAREL, R. K. and OTSUKA, K. 2004. Efficiency of timber production in community and private forestry in Nepal. Environment and Development Economics 9: 539-561.

SCHRECKENBERG, K. and LUTTRELL, C. 2009. Participatory forest management: a route to poverty reduction? International Forestry Review 11(2): 221238.

SCHRECKENBERG, K., LUTTRELL, C. and MOSS, C. 2006. Participatory forest management: an overview. In: Forest Policy and Environment Programme: Grey Literature. London, Forest Policy and Environment Programme, Overseas Development Institute.

SPRINGATE-BAGINSKI, O., Dev, O. P., YADAV, N. P. and SOUSSAN, J. 2003. Community forest management in the middle hills of Nepal: the changing context. Journal of Forest and Livelihood 3 (1): 5-10.

TEMPHEL, K. J., THINLEY, K., WANGCHUK, T. and MOKTAN, M. R. 2005. Assessment of Community Forestry Implementation in Bhutan. Thimphu, Department of Forests, Ministry of Agriculture, Royal Government of Bhutan.

TFDP. 2000. Social Forestry in Eastern Bhutan. Khangma, Third Forestry Development Project, Department of Forestry Services, SDC/World Bank/Ministry of Agriculture, Royal Government of Bhutan.

UNDP. 2006. Human Development Report 2006. New York, Palgrave Macmillan.

UNESCO. 2008. Bhutan Country Profile. United Nations Educational, Scientific and Cultural Organization (UNESCO) 2008 [cited 25 February 2008]. Available from http://www.unescobkk.org/index.php?id=3574.

UPRETY, D. R. 2006. Conflicts in natural resource management - examples from community forestry. Jahrbuch der Österreichischen Gesellschaft für Agrarökonomie 15: 43-155.

VARALAKSHMI, V. 2002. Joint Forest Management and Conflict in Haryana, India. In: MEANS, K. and JOSAYMA, C. (eds.) Community-Based Forest Resource Conflict Management. Rome, Food and Agriculture Organization, United Nations.

WANGCHUK, T. 2000. Change in the land use system in Bhutan: ecology, history, culture, and power. Journal of Bhutan Studies 12 (1).

WHITE, A., and MARTIN, A. 2002. Who owns the world's forests? Forest tenure and public forests in transition. Washington, Center for International Environmental Law. WRI. 2007. Country Profiles. World Resources Institute 
2007 [cited 29 March 2007]. Available from http:// earthtrends.wri.org/index.php.

YADAV, N. P., DEV, O. P., SPRINGATE-BAGINSKI, O. and SOUSSAN, J. 2003. Forest management and utilization under community forestry. Journal of Forest and Livelihood, 3 (1): 37-50. 